\author{
R.Kh. Dzhanabekova, N.Kh. Ibrayev \\ Institute of Molecular Nanophotonics, Ye.A. Buketov Karaganda State University, Kazakhstan \\ (E-mail:rumiya_j@mail.ru)
}

\title{
SERS substrates based on silver nanoparticles and graphene oxide
}

\begin{abstract}
Simple work methods for preparing active coatings for surface-enhanced Raman scattering (SERS) are demonstrated in the article. SERS active films of colloidal silver nanoparticles and composites based on graphene oxide and silver nanoparticles were obtained. The prepared disperse solutions of silver nanoparticles and graphene oxide/Ag nanoparticles composites have different stability. Using a scanning electron microscope, the structure of the prepared films was studied. A comparative characteristic of the obtained SERS active substrates is given. The dye Rhodamine $6 \mathrm{G}$ was used as the test substance. It was shown that the smallest enhancement of the Raman signal is produced by a coating of colloidal silver nanoparticles, while the graphene oxide/Ag nanoparticles composite obtained by the 2 -stage method provides the greatest gain. The different ability to amplify the Raman signal is explained by the difference in the structure and composition of the obtained SERS active films. All prepared coatings make it easy to detect low dye concentrations (from a $10^{-6} \mathrm{M}$ solution) both with resonance $(532 \mathrm{~nm})$ and nonresonance $(632.8 \mathrm{~nm})$ excitation.
\end{abstract}

Keywords: surface-enhanced Raman scattering, plasmon resonance, sensor, composite, graphene oxide, silver nanoparticles, signal enhancement.

\section{Introduction}

The phenomenon of surface-enhanced Raman scattering (SERS), discovered in the seventies of the last century, attracts the genuine attention of researchers working in various fields of science. SERS is manifested in a significant amplification (up to $10^{10}$ times) of the signal of Raman scattering of light from a substance on the surface of noble metal nanoparticles, which has a nanometer roughness [1,2]. The SERS effect is explained mainly by two mechanisms: electromagnetic and chemical $[2,3]$. The electromagnetic mechanism is predominant and consists in strengthening the electromagnetic field in the near field of metal nanoparticles as a result of the plasmon effect $[1,2,4]$. The chemical mechanism is explained by the adsorption of an analyte molecule on the surface of metal nanoparticles with the formation of a charge-transfer complex $[4,5]$.

Thus, the SERS method, along with the advantages of Raman spectroscopy, namely: selectivity, the absence of complex sample preparation, and simplicity of execution, has great sensitivity. These characteristics of the method make it a valuable tool for achieving analytical goals in chemistry, ecology, biology, medicine, etc. Since the discovery of the SERS phenomenon, a large number of works have appeared on the creation of SERS sensors. However, to date, only a small number of developments have become commercially available and put into practice. In this regard, the creation of SERS-active substrates remains an urgent task.

Graphene and its derivatives such as graphene oxide, reduced graphene oxide and graphene oxide doped with nitrogen are a new material in surface enhanced Raman spectroscopy. A number of studies have shown that graphene coatings are capable of amplifying the Raman signal by the chemical mechanism. The so-called graphene-enhanced Raman scattering has opened up new possibilities for the detection of substances [6-8]. Graphene and its derivatives are much cheaper than noble metal nanoparticles, have high adsorption capacity and effectively quench luminescence, which interferes with the measurement of Raman spectra. However, substrates based on pure graphene material provide low amplifications; therefore, composite materials based on graphene and noble metals are of more interest $[9,10]$.

In this work, we obtained SERS-active substrates based on colloidal silver nanoparticles and composites graphene oxide-silver nanoparticles (GO/AgNPs), prepared by one-stage and two-stage methods, and also performed a comparative analysis of their properties.

\section{Experiment}

Synthesis of GO/AgNPs composite by a single-stage method (composite I). The synthesis was performed according to the modified method described in [11]. $0.5 \mathrm{mg}$ of $\mathrm{GO}$ was mixed with $10 \mathrm{ml}$ of deionized water, treated in an ultrasonic bath for 2 hours to obtain a dispersed solution. $3 \%$ ammonia solution was 
added dropwise to $3 \mathrm{ml}$ of $0.2 \mathrm{M}$ silver nitrate solution. First, brown precipitate of silver oxide forms, which generate water-soluble ammonia complex with the further added ammonia. The resulting solution of the ammonia complex of silver was added to dispersed solution of GO and treated with ultrasound for 30 min. Next, in the solution heated to $50^{\circ} \mathrm{C}$, with vigorous stirring on a magnetic stirrer, $65 \mu 1$ of $42 \%$ formic acid solution was added dropwise. The reaction mixture was kept at this temperature for 30 minutes. Then the precipitate was separated in a centrifuge ( $4000 \mathrm{rpm}, 25$ minutes), washed with deionized water several times. $10 \mathrm{ml}$ of deionized water was added to the obtained precipitate and dispersed in ultrasound for 20 minutes.

2-stage synthesis of the GO/AgNPs composite (composite II). The synthesis technique is described in more detail in [12]:

1st stage. $0.1 \mathrm{M} \mathrm{NaOH}$ solution was added dropwise to $0.02 \mathrm{M}$ aqueous solution of $\mathrm{AgNO}_{3}$ until brown precipitate formed. The resulting precipitate was left to stand for $10 \mathrm{~min}$, the supernatant was drained, the precipitate was washed 3 times with deionized water. $10 \mathrm{ml}$ of water was added to the precipitate, then $12 \%$ ammonia solution was added dropwise until the precipitate was completely dissolved. The resulting ammonia complex was mixed with $4 \mathrm{ml}$ of aqueous GO suspension $(0.4 \mu \mathrm{g} / \mathrm{ml})$, which was pretreated for 2 hours with ultrasound. The mixture was then heated at $100{ }^{\circ} \mathrm{C}$ for $30 \mathrm{~min}$ with vigorous stirring on a magnetic stirrer.

2nd stage. To the dispersion obtained in the first stage, $2 \mathrm{ml}$ of freshly prepared $0.001 \mathrm{M} \mathrm{AgNO}_{3}$ solution was added with stirring. The mixture was stirred at room temperature for 30 minutes, then freshly prepared equimolar solution of ascorbic acid was added and stirring was continued at room temperature for another one and a half hour. Then the solution was centrifuged, the supernatant was drained, the precipitate was washed several times with deionized water. $10 \mathrm{ml}$ of deionized water was added to the obtained precipitate and sonicated for 20 minutes.

Obtaining of colloidal solution of silver nanoparticles. Silver nanoparticles in water are synthesized in the same manner as in the case of composite II.

Preparation of SERS active coatings. To prepare the composite-based SERS substrates, $150 \mu \mathrm{l}$ of the corresponding dispersed solution was applied to the surface of the coverslip, and the coating was dried under natural conditions for 20 hours.

To obtain a coating of silver nanoparticles, the cover glass was immersed in the prepared colloidal solution for 72 hours, then the substrate was washed in deionized water and dried under natural conditions.

Measurements. The structure of colloidal silver films and composites and their elemental composition were studied using a TESCAN MIRA 3 scanning electron microscope.

To study the SERS activity of the obtained coatings, Raman spectra of Rhodamine 6G (Rh6G) were measured. $5 \mu \mathrm{l}$ of $10^{-4} \mathrm{M}$ or $10^{-6} \mathrm{M}$ aqueous dye solution was dropped into different sections of the active film; the droplets were dried at room temperature in air.

Raman spectra were measured on a Confotec MR 520 confocal microscope. Raman spectra of the samples were excited at 532 and $632.8 \mathrm{~nm}$. The laser power on the surface of the samples was varied depending on the sample and the exciting radiation; the spectrum accumulation time was no more than $10 \mathrm{~s}$. To evaluate the amplification of the intensity of vibrational spectra on the SERS active substrates, we compared the intensities of the Raman spectra of the dye obtained under the same conditions on pure glass.

\section{Results and discussion}

In the present work, SERS active coatings were obtained in different ways: by deposition of silver nanoparticles from a colloidal solution onto a solid substrate and by applying a dispersed solution of GO/AgNPs composites onto a solid substrate, followed by drying. In all cases, silver nanoparticles were obtained by reduction of $\mathrm{Ag}^{+}$through the formation of an ammonia complex. In one case, only colloidal silver nanoparticles were synthesized; in the other two cases, the reduction was carried out in the presence of graphene oxide. The obtained silver hydrosol is not very stable, and the nanoparticles settle for several days. The dispersed solution of composite I is stable for several weeks, then the particles coagulate, sonication returns them to dispersed state. The dispersed solution of composite II remains stable for several months, without a significant loss of SERS activity.

Figure 1 shows SEM images of synthesized composites and colloidal Ag nanoparticles. It can be seen from the photo of the composites that Ag NPs are fixed on the surface of graphene oxide «flakes» and are evenly distributed. For composite I, the sizes of nanoparticles vary from 20 to $100 \mathrm{~nm}$ with a predominance of particles with sizes of the order of 50-60 nm. Particles are located from each other at distances exceeding their sizes. For composite II, the size of most of the particles is $40-70 \mathrm{~nm}$, along with them there are also 
particles with sizes of the order of $100 \mathrm{~nm}$. Silver nanoparticles are located almost close to each other, forming a rough surface on graphene oxide sheets. On a substrate with a silver film obtained by deposition from colloidal solution, the nanoparticles form loose micrometer clusters consisting of particles ranging in size from 40 to $80 \mathrm{~nm}$.

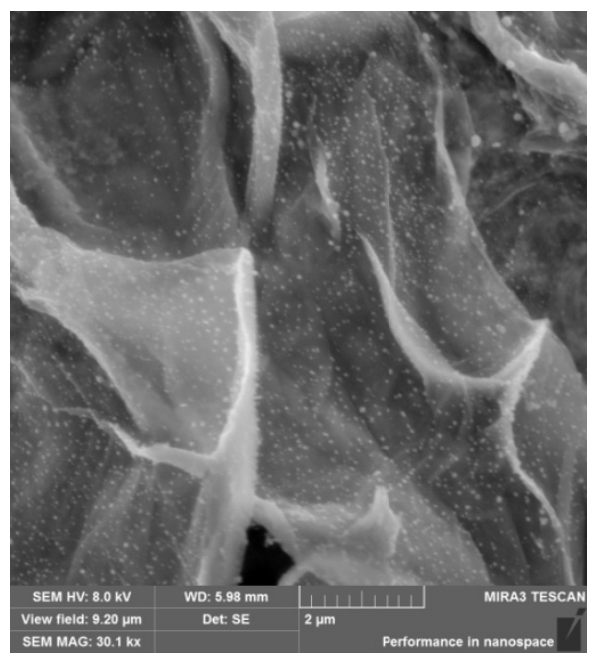

$a$

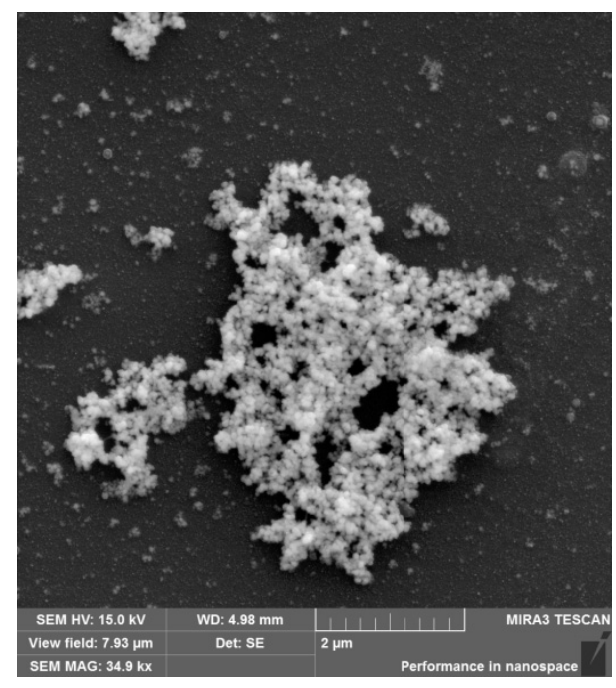

c
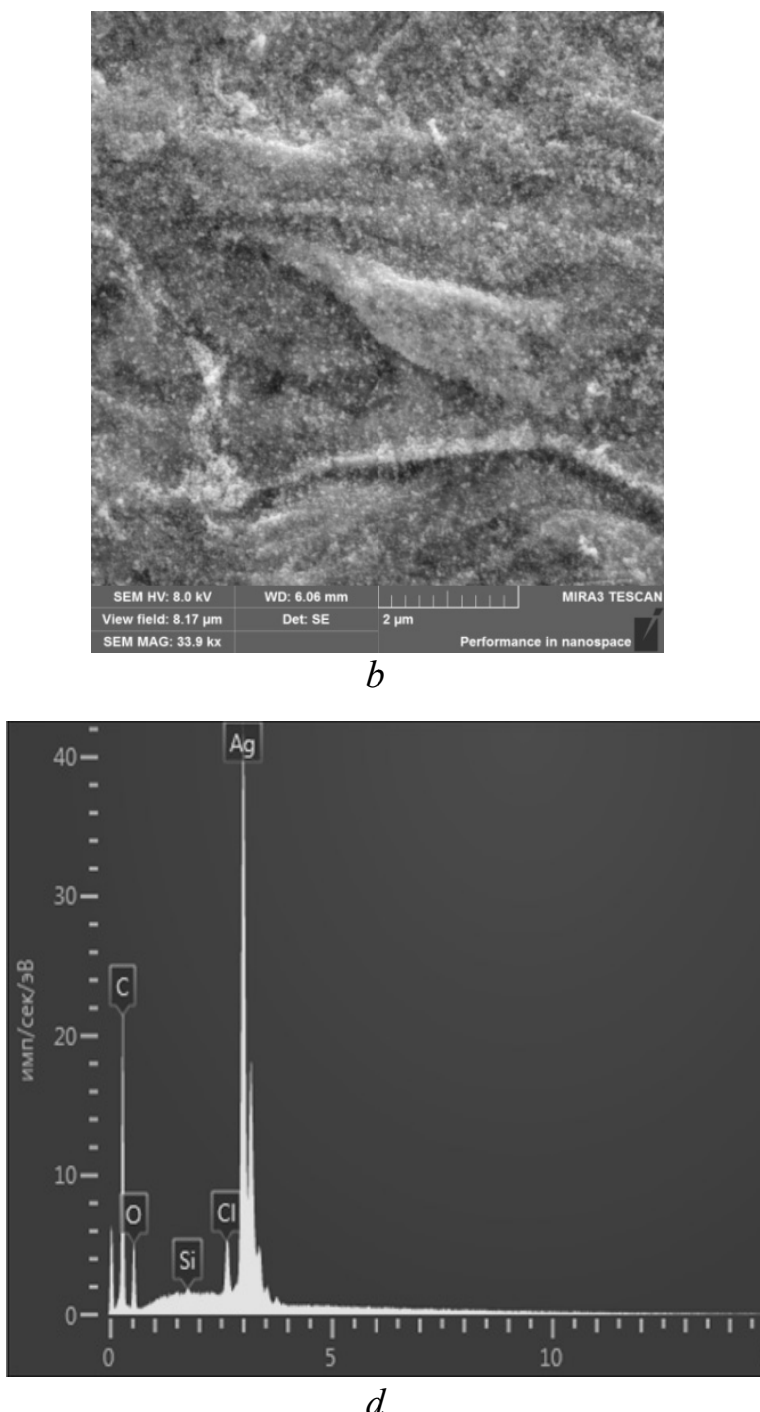

$a-c-$ composite I, composite II, colloidal Ag NPs, respectively; $d$ - energy-dispersive X-ray analysis spectrum of composite II

Figure 1. SEM images and the X-ray spectrum of SERS active coatings

Figure 2 shows the Raman spectra of graphene oxide and composite I. Both spectra have characteristic GO bands: $\mathrm{D}\left(1346 \mathrm{~cm}^{-1}\right), \mathrm{G}\left(1602 \mathrm{~cm}^{-1}\right)$, and $2 \mathrm{D}\left(2686 \mathrm{~cm}^{-1}\right)$. The $\mathrm{I}_{\mathrm{D}} / \mathrm{I}_{\mathrm{G}}$ ratio usually correlates with the number of defects and disordered clusters on the surface of $\mathrm{GO}[13,14]$. For the composite, the $\mathrm{I}_{\mathrm{D}} / \mathrm{I}_{\mathrm{G}}$ ratio remained virtually unchanged (Table 1), which indicates that the introduction of silver nanoparticles did not affect the surface properties of GO. The composite intensity is significantly higher compared to the Raman spectrum of pure graphene oxide (Table 1), which demonstrates signal amplification due to plasmon resonance of AgNPs [15]. 


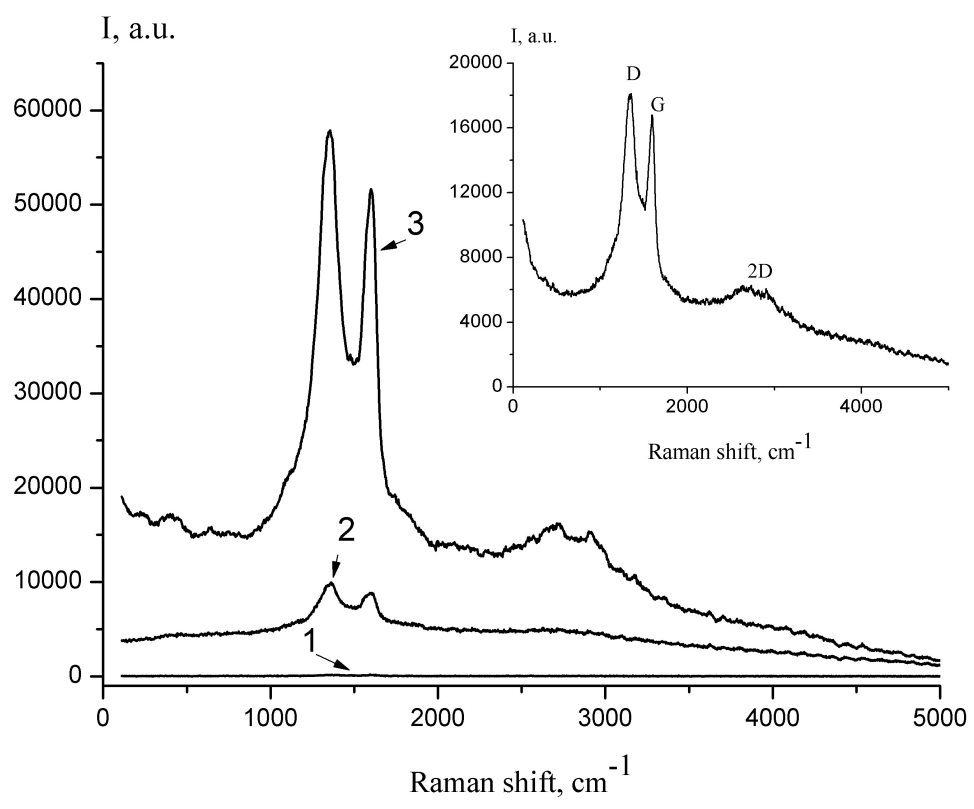

Figure 2. Raman spectra of the GO (1) and the SERS spectrum of composite I $(2,3)\left(\lambda_{\text {exc }}\right.$ is $632.8 \mathrm{~nm}$, laser power on the samples is $1.1 \mathrm{~mW}$ ). The inset shows the Raman spectrum of the GO at laser power of $35 \mathrm{~mW}$

T a b l e 1

Comparison of the intensification intensities of the characteristic bands of the Raman spectra of GO and composite $I$ in different parts of the sample upon excitation at $632.8 \mathbf{~ n m}$. The laser power on the sample is $3.5 \mathrm{~mW}$

\begin{tabular}{|c|c|c|c|c|}
\hline \multicolumn{2}{|c|}{ Sample } & $\mathrm{I}_{\mathrm{D}} / \mathrm{I}_{\mathrm{G}}$ & Enhancement of D signal $\left(1346 \mathrm{~cm}^{-1}\right)$ & Enhancement of $\mathrm{G}$ signal $\left(1602 \mathrm{~cm}^{-1}\right)$ \\
\hline \multicolumn{2}{|c|}{$\mathrm{GO}$} & 1.10 & - & - \\
\hline \multirow{3}{*}{$\mathrm{GO} /$ AgNPs } & point 1 & 1.13 & 39 & 38 \\
\cline { 2 - 5 } & point 2 & 1.08 & 73 & 72 \\
\cline { 2 - 5 } & point 3 & 1.12 & 62 & 61 \\
\hline
\end{tabular}

Different values of the intensity of the Raman spectra in different parts of the substrate indicate the heterogeneity of the active layer; therefore, to more correctly determine the gain, it is necessary to take the average value of the intensities of the spectra recorded from different parts of the sensor. Below, the average spectral gain values obtained for 7 points will be given.

The Rh6G, the Raman spectrum of which is well studied, was taken as a marker substance. The Raman spectrum of Rh6G is characterized by medium and high intensity bands at the Raman shift of 611,771 and $1125 \mathrm{~cm}^{-1}$, associated with vibrations of the aromatic ring in the plane and out of the plane, and $\mathrm{C}-\mathrm{H}$ vibrations in the plane, as well as bands at $1189,1310,1360,1508$ and $1649 \mathrm{~cm}^{-1}$, which relate to stretching vibrations of aromatic $\mathrm{C}-\mathrm{C}$ bonds [16-18].

When samples are excited at $632.8 \mathrm{~nm}$, the Raman spectrum is very weak in intensity for a sample with the dye on pure glass (Fig. 3), while for Rh6G on all three SERS-active substrates, the Raman spectrum is quite intense with good resolution of characteristic peaks (Fig. 3). The highest signal enhancement (64 times at Raman shift of $1361 \mathrm{~cm}^{-1}$ at a laser power of almost 3 times less) is provided by a substrate coated with composite II (Table 2).

Figure 4 shows the SERS spectra of Rh6G deposited on prepared substrates from $10^{-6} \mathrm{M}$ solution, upon excitation of the spectra at $632.8 \mathrm{~nm}$. The figure clearly shows that in the spectra obtained on composites, in the range of 1200-1700 $\mathrm{cm}^{-1}$, the SERS spectrum of graphene oxide makes a significant contribution, «hiding» individual characteristic bands of the dye. At the same time, all spectral bands of Rh6G are clearly manifested on the colloidal silver film. 


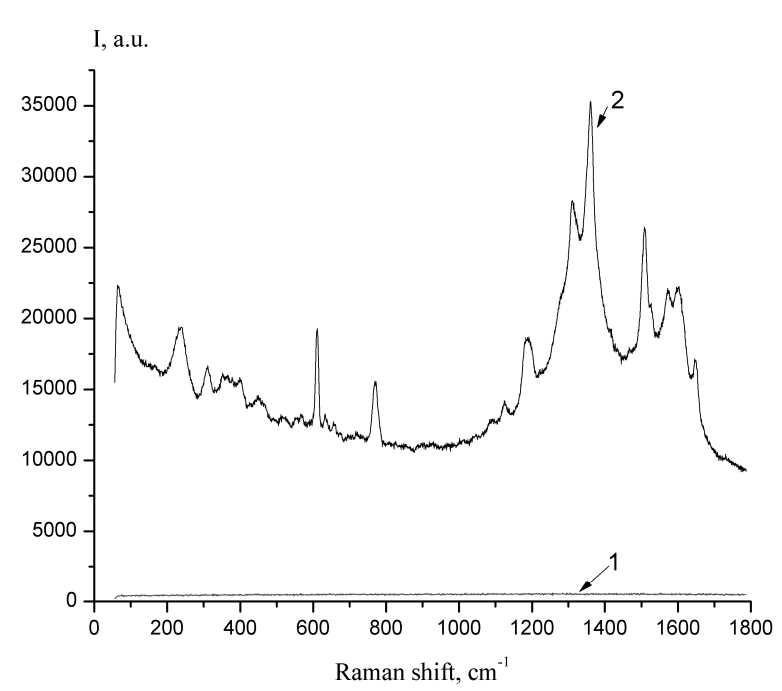

$a$

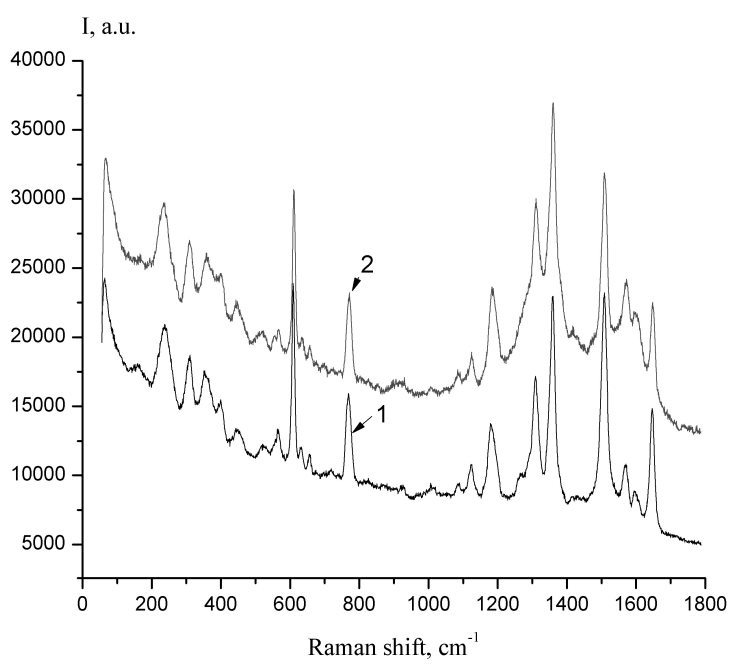

$b$

Figure 3. SERS spectra of Rh6G $\left(10^{-4} \mathrm{M}\right)$ on composite II $(\mathrm{a}, 2)$, composite I $(\mathrm{b}, 2)$, on AgNPs $(b, 1)$ and Raman spectrum of Rh6G on glass $(a, 1)$ excited at $632.8 \mathrm{~nm}$

Ta b l e 2

Comparison of intensifications of intensities at characteristic bands of the SERS spectra of $\operatorname{Rh}^{6 G}\left(10^{-4} \mathrm{M}\right)$ on the studied substrates

\begin{tabular}{|c|c|c|c|c|c|c|}
\hline \multirow{2}{*}{$\begin{array}{c}\text { Substrate } \\
\text { coating }\end{array}$} & $\begin{array}{c}\text { Laser power } \\
\text { on the sample, } \\
\mathrm{mW}\end{array}$ & \multicolumn{5}{|c|}{$\begin{array}{c}\text { Enhancement of the intensity of the Raman signal } \\
\text { at the characteristic bands of Rh6G }\end{array}$} \\
\cline { 3 - 7 } & 3.5 & $611 \mathrm{~cm}^{-1}$ & $772 \mathrm{~cm}^{-1}$ & $1188 \mathrm{~cm}^{-1}$ & $1361 \mathrm{~cm}^{-1}$ & $1508 \mathrm{~cm}^{-1}$ \\
\hline AgNPs & 17 & 12 & 10 & 17 & 20 \\
\hline Composite I & 3.5 & 22 & 16 & 19 & 25 & 25 \\
\hline Composite II & 1.1 & 40 & 31 & 23 & 64 & 55 \\
\hline
\end{tabular}

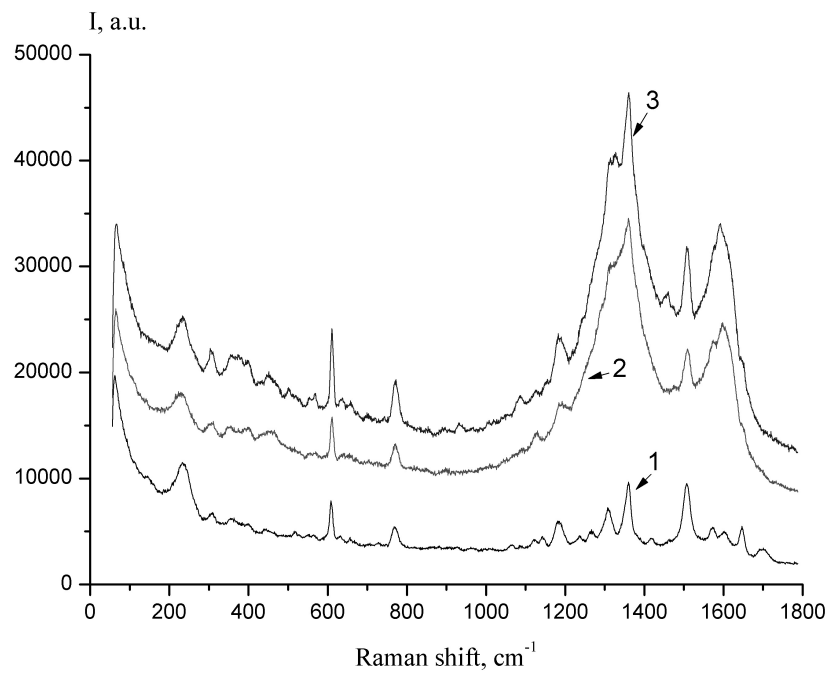

Figure 4. SERS spectra of Rh6G (10 $\left.{ }^{-6} \mathrm{M}\right)$ on AgNPs (1), on composite I (2), on composite II (3) excited at $632.8 \mathrm{~nm}$ (laser power in cases 1 and 2 are $3.5 \mathrm{~mW}$, in case 3 is $1.1 \mathrm{~mW}$ )

As is known, the maximum of the Rh6G absorption band is in the region of $530 \mathrm{~nm}$. By exciting this well-luminescent dye at the absorption wavelength, it is quite naturally to observe its fluorescence, at the same time the excitation of molecules in the absorption band should lead to resonant Raman scattering, which is much stronger in intensity than nonresonant Raman scattering [2]. Figure 5 shows the Raman spectra of Rh6G obtained upon excitation at $532 \mathrm{~nm}$. In the spectrum of the dye on pure glass, we see mainly lu- 
minescence. The fluorescent component eliminates the presence of characteristic Raman peaks (Fig. 5, inset). At the same time, for Rh6G deposited on the surface of composites and the AgNPs film, intense characteristic bands are clearly observed in the SERS spectra (Fig. 5). Due to the strong influence of fluorescence at resonant excitation, it is difficult to correctly determine the Raman enhancement.

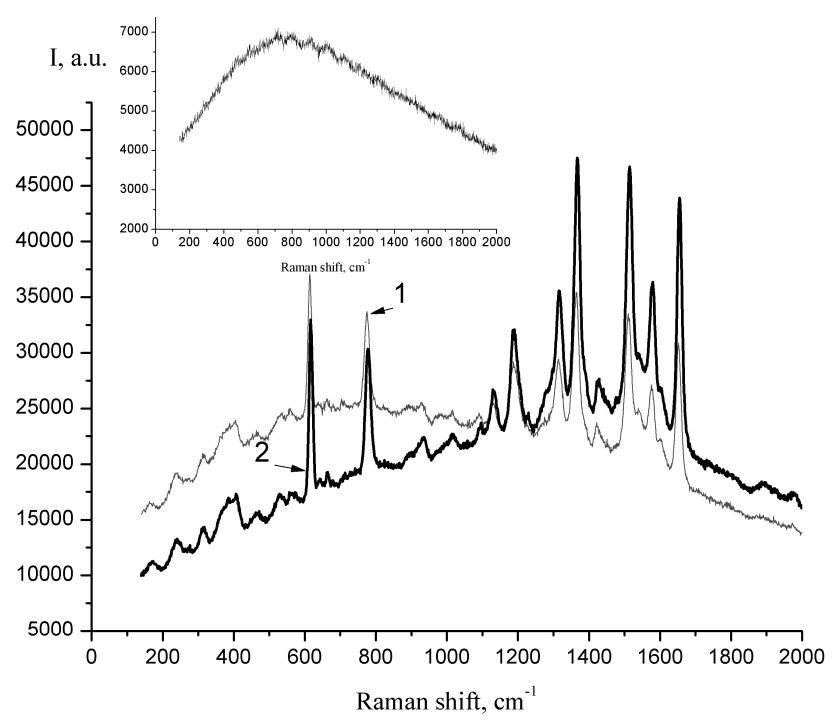

Figure 5. SERS spectra of Rh6G $\left(10^{-6} \mathrm{M}\right)$ on on AgNPs (1) (laser power on the sample is $0.22 \mathrm{~mW}$ ) and on composite (2) (laser power on the sample is $0.696 \mathrm{~mW}$ ). The inset shows the Raman spectrum of Rh6G $\left(10^{-6} \mathrm{M}\right)$ on glass (the laser power on the sample is $0.696 \mathrm{~mW}$ )

\section{Conclusion}

SERS-active films based on colloidal silver nanoparticles and composites based on graphene oxide and silver nanoparticles were obtained. All three coatings differ in structure and ability to amplify the Raman signal. The smallest enhancement in the intensity of Raman spectra was obtained on a coating of silver nanoparticles, while the highest gain was provided by composite II. This can be explained by the fact that only the electromagnetic mechanism contributes to the amplification of the Raman signal on a substrate of $\mathrm{Ag}$ NPs. Greater enhancement on the composite films are due to both the plasmon effect of silver nanoparticles and the interaction of dye molecules with graphene oxide. The close arrangement of silver nanoparticles on graphene oxide particles, contributing to the formation of so-called «hot spots» [4], explains the largest Raman signal amplification on composite II.

The obtained dispersed solutions of the composites remain stable for several weeks to several months and at the same time retain their SERS activity.

This work was carried out as part of the research project BR05236691, funded by the Ministry of Education and Science of the Republic of Kazakhstan.

\section{References}

1 Moskovits M. Surface-enhanced spectroscopy / M. Moskovits // Rev. Mod. Phys. — 1985. — Vol. 57, No. 3. — P. $783-826$.

2 Etchegoin L.R. Principles of Surface-Enhanced Raman Spectroscopy and Related Plasmonic Effects / L.R.Etchegoin. Amsterdam: Elsevier Science, 2008. - 633 p.

3 Гигантское комбинационное рассеяние / под ред. Р. Ченга, Т. Фуртака. - М.: Мир, 1984. — 408 с.

4 Поверхностно-усиленная рамановская спектроскопия (SERS): аналитические, биофизические и биомедицинские приложения / под ред. С.М. Шлюкера. - М.: Техносфера, 2017. - 328 с.

5 Cardinal M.F. Expanding applications of SERS through versatile nanomaterials engineering / M.F. Cardinal, E.V. Ende, R.A. Hackler, M.O. McAnally, P.C. Stair, G.C. Schatz et al. // Chem. Soc. Rev. — 2017. — Vol. 46. - P. 3886-3903.

6 Ling X. Can Graphene be used as a Substrate for Raman Enhancement? / X. Ling, L.M. Xie, Y. Fang, H. Xu, H.L. Zhang, J. Kong, et al. // Nano Lett. — 2010. — Vol. 10. — P. 553-561.

7 Kang L. Recent progress in the applications of graphene in surface-enhanced Raman scattering and plasmon-induced catalytic reactions / L. Kang, J. Chu, H. Zhao, P. Xu, M. Sun // J. Mater. Chem. C. — 2015. — Vol. 3. — P. 9024-9037. 
8 Lv R. Nitrogen-doped graphene: beyond single substitution and enhanced molecular sensing [Электронный ресурс] / R. Lv, Q. Li, A. Botello-Me'ndez, T. Hayashi, B. Wang // Sci. Rep. - 2012. - Vol. 2. — P. 586. - Режим доступа: https://www.ncbi.nlm.nih.gov/pmc/articles/PMC3421434/

9 Xie L. Graphene as a Substrate to Suppress Fluorescence in Resonance Raman Spectroscopy / L. Xie, X. Ling, Y. Fang, J. Zhang, Z. Liu // J. Am. Chem. Soc. — 2009. - Vol. 131. — P. 9890-9891.

10 Jiang Y. Graphene Oxide-Silver Nanoparticles in Molecularly-Imprinted Hybrid Films Enabling SERS Selective Sensing [Электронный ресурс] / Y. Jiang, D. Carboni, L. Malfatti, P. Innocenzi // Materials. — 2018. — Vol. 11. — P. 1674. — Peжим доступа: https://www.mdpi.com/1996-1944/11/9/1674

11 Wang G. Synthesis and characterization of Ag nanoparticles assembled in ordered array pores of porous anodic alumina by chemical deposition / G. Wang, Ch. Shi, N. Zhao, X. Du // Materials Letters. - 2007. — Vol. 61. - P. 3795-3797.

12 Веселова И.А. Композиция, обладающая ГКР-активностью для определения полиароматических гетероциклических серосодержащих соединений в углеводородных продуктах, способ получения композиции, планарный твердофазный оптический сенсор на ее основе и способ его получения, применение сенсора для анализа полиароматических гетероциклических серосодержащих соединений / И.А. Веселова, М.О. Володина, А.В. Сидоров, О.Е. Еремина, Е.А. Гудилин // Инновационный патент на изобретение Российской Федерации. MPK G01N 21/63, B82P 1/00, № 2627980 C1/ Заявл. 16.09.2016; Опубл. 14.08.2017.

13 Stankovich S. Synthesis of graphene-based nanosheets via chemical reduction of exfoliated graphite oxide / S. Stankovich, D.A. Dikin, R.D. Piner, K.A. Kohlhaas, A. Kleinhammes // Carbon. — 2007. — Vol. 45. — P. 1558-1565.

14 Cançado L.G. Quantifying Defects in Graphene via Raman Spectroscopy at Different Excitation Energies / L.G. Cançado, A. Jorio, E.H. Martins Ferreira, F. Stavale, C.A. Achete // Nano Lett. — 2011. — Vol. 11. — P. 3190-3196.

15 Resmini M. Microgels and Nanogels with Catalytic Activity / M. Resmini, K. Flavin, D. Carboni // Top. Curr. Chem. 2012. - Vol. 325. - P. 307-342.

16 Tang H. Arrays of cone-shaped $\mathrm{ZnO}$ nanorods decorated with Ag nanoparticles as 3D surface-enhanced raman scattering substrates for rapid detection of trace polychlorinated biphenyls / H. Tang, G. Meng, Q. Huang, Z. Zhang, Z. Huang, C. Zhu // Adv. Funct. Mater. - 2012. - Vol. 22. - P. 218-224.

17 Zheng Y. Surface-enhanced Raman scattering (SERS) substrate based on large-area well-defined gold nanoparticle arrays with high SERS uniformity and stability / Y. Zheng, W. Wang, Q. Fu, K. Wu, K.M. Shayan // Chempluschem. — 2014. — Vol. 79. - P. 1622-1630.

18 Liu D. Fabrication and characterization of highly ordered Au nanocone array-patterned glass with enhanced SERS and hydrophobicity / D. Liu, Q. Wang, J. Hu // Appl. Surf. Sci. — 2015. — Vol. 356. — P. 364-369.

\section{P.Х. Джанабекова, Н.Х. Ибраев}

\section{Күміс нанобөлшектері және графен оксидінің негізіндегі БКРС төсеніштері}

Мақалада ГКШ белсенді қабаттарын жасаудың қарапайым әдістері көрсетілген. Коллоидті күміс нанобөлшектерінің және графен оксиді мен күміс нанобөлшектері негізінде композиттердің ГКШ белсенді қабыршақтары алынған. Дайындалған күміс нанобөлшектері мен композиттердің дисперсиялық ерітінділері әртүрлі тұрақтылыққа ие. Дайындалған қабыршақтардың құрылысы сканерлеуші электрондық микроскоп арқылы зерттелген. Алынған ГКШ белсенді қабыршақтарының салыстырмалы сипаттамалары келтірілген. Тестіленетін зат ретінде родамин 6Ж бояғышы қолданылған. Коллоидті күміс нанобөлшектері қабатында комбинациондық шашырау сигналының ең аз, ал 2-сатылы әдіспен алынған графен оксиді/Ag НБ композитінде ең үлкен күшею көрсетілген. Комбинациондық шашырау сигналын күшейту қабілетінің әртүрлі болуы алынған ГКШ белсенді қабыршақтарының құрылымы мен құрамындағы айырмашылықпен түсіндірілген. Барлық дайындалған жабындар резонанстық (532 нм) және резонанстық емес (632,8 нм) қозу кезінде де бояғыштың төмен концентрациясын $\left(10^{-6} \mathrm{M}\right.$ ерітіндіден) оңай анықтауға мүмкіндік береді.

Кілт сөздер: жарықтың гигантты комбинациондық шашырауы, плазмондық резонанс, сенсор, графен оксиді, күміс нанобөлшектері, сигналдың күшеюі.

\section{P.Х. Джанабекова, Н.Х. Ибраев}

\section{ПУРС подложки на основе наночастиц серебра и оксида графена}

В статье продемонстрированы простые способы приготовления активных покрытий для гигантского комбинационного рассеяния (ГКР). Получены ГКР активные пленки наночастиц коллоидного серебра и композитов на основе оксида графена и наночастиц серебра. Приготовленные дисперсные растворы наночастиц серебра и композитов обладают различной стабильностью. С помощью сканирующего электронного микроскопа исследована структура приготовленных пленок. Дана сравнительная характеристика полученных ГКР активных подложек. В качестве тестируемого вещества был использован краситель родамин 6Ж. Показано, что наименьшее усиление сигнала комбинационного рассеяния дает покрытие из наночастиц коллоидного серебра, а наибольшее усиление обеспечивает композит оксида 
графена/нч Ag, полученный 2-стадийным методом. Разная способность к усилению сигнала комбинационного рассеяния объясняется различием в структуре и составе полученных ГКР активных пленок. Все приготовленные покрытия позволяют легко обнаруживать низкие концентрации красителя (из раствора порядка $\left.10^{-6} \mathrm{M}\right)$ как при резонансном (532 нм), так и нерезонансном $(632,8$ нм) возбуждении.

Ключевые слова: гигантское комбинационное рассеяние света, плазмонный резонанс, сенсор, оксид графена, наночастицы серебра, усиление сигнала.

\section{References}

1 Moskovits, M. (1985). Surface-enhanced spectroscopy. Rev. Mod. Phys., 57, 3, 783-826.

2 Etchegoin, L.R. (2008). Principles of Surface-Enhanced Raman Spectroscopy and Related Plasmonic Effects. Amsterdam: Elsevier Science.

3 Chang, R., \& Furtak, T. (Eds.). (1984). Hihantskoe kombinatsionnoe rasseianie [Surface Enhanced Raman Scattering]. Moscow: Mir [in Russian].

4 Shluker, C. (Eds.). (2017). Poverkhnostno-usilennaia ramanovskaia spektroskopiia (SERS): analiticheskie, biofizicheskie $i$ biomeditsinskie prilozheniia [Surface-enhanced Raman spectroscopy (SERS): analysis, biophysical and biomedical applications]. Moscow: Technosphera [in Russian].

5 Cardinal, M.F., Ende, E.V., Hackler, R.A., McAnally, M.O., Stair, P.C., \& Schatz, G.C., et al. (2017). Expanding applications of SERS through versatile nanomaterials engineering. Chem. Soc. Rev., 46, 3886-3903.

6 Ling, X., Xie, L.M., Fang, Y., Xu, H., Zhang, H.L., \& Kong J., et al. (2010). Can Graphene be used as a Substrate for Raman Enhancement? Nano Lett., 10, 553-561.

7 Kang, L., Chu, J., Zhao, H., Xu, P., \& Sun, M. (2015). Recent progress in the applications of graphene in surface-enhanced Raman scattering and plasmon-induced catalytic reactions. J. Mater. Chem. C., 3, 9024-9037.

8 Lv, R., Li, Q., Botello-Mendez, A., Hayashi, T., \& Wang, B. (2012). Nitrogen-doped graphene: beyond single substitution and enhanced molecular sensing. Sci. Rep., 2, 586. Retrieved from https://www.ncbi.nlm.nih.gov/pmc/articles/PMC3421434/

9 Xie, L., Ling, X., Fang, Y., Zhang, J., \& Liu, Z. (2009). Graphene as a Substrate to Suppress Fluorescence in Resonance Raman Spectroscopy. J. Am. Chem. Soc., 131, 9890-9891.

10 Jiang, Y., Carboni, D., Malfatti, L., \& Innocenzi, P. (2018). Graphene Oxide-Silver Nanoparticles in Molecularly-Imprinted Hybrid Films Enabling SERS Selective Sensing. Materials, 11, 1674. Retrieved from https://www.mdpi.com/1996-1944/11/9/1674.

11 Wang, G., Shi, Ch., Zhao, N., \& Du, X. (2007). Synthesis and characterization of Ag nanoparticles assembled in ordered array pores of porous anodic alumina by chemical deposition. Materials Letters, 61, 3795-3797.

12 Veselova, I.A., Volodina, M.O., Sidorov, A.V., Eremina, O.E., \& Gudilin, E.A. (2017). Kompozitsiia, obladaiushchaia GKRaktivnostiu dlia opredeleniia poliaromaticheskikh heterotsiklicheskikh soedinenii $\mathrm{v}$ uhlevodorodnykh produktakh, sposob polucheniia kompozitsii, planarnyi tverdofaznyi opticheskii sensor na ee osnove i sposob yeho polucheniia, primeneniie sensora dlia analiza poliaromaticheskikh heterotsiklicheskikh serosoderzhashchikh soedinenii [A composition having HCR activity for determining polyaromatic heterocyclic sulfur-containing compounds in hydrocarbon products, a method for producing a composition, a planar solid-phase optical sensor based on it and a method for producing it, use of a sensor for analysis of polyaromatic heterocyclic sulfurcontaining compounds]. Innovative patent of the Russian Federation: MPK G01N 21/63, B82P 1/00, No 2627980 C1, Decl. 16.09.2016, Publ. 14.08.2017 [in Russian].

13 Stankovich, S., Dikin, D.A., Piner, R.D., Kohlhaas, K.A., \& Kleinhammes, A. (2007). Synthesis of graphene-based nanosheets via chemical reduction of exfoliated graphite oxide. Carbon, 45, 1558-1565.

14 Cançado, G., Jorio, A., Martins Ferreira, E.H., Stavale, F., \& Achete, C.A. (2011). Quantifying Defects in Graphene via Raman Spectroscopy at Different Excitation Energies. Nano Lett., 11, 3190-3196.

15 Resmini, M., Flavin, K., \& Carboni, D. (2012). Microgels and Nanogels with Catalytic Activity. Top. Curr. Chem., 325, $307-342$.

16 Tang, H., Meng, G., Huang, Q., Zhang, Z., Huang, Z., \& Zhu, C. (2012). Arrays of cone-shaped ZnO nanorods decorated with $\mathrm{Ag}$ nanoparticles as 3D surface-enhanced raman scattering substrates for rapid detection of trace polychlorinated biphenyls. Adv. Funct. Mater., 22, 218-224.

17 Zheng, Y., Wang, W., Fu, Q., Wu, K., \& Shayan, K.M. (2014). Surface-enhanced Raman scattering (SERS) substrate based on large-area well-defined gold nanoparticle arrays with high SERS uniformity and stability. Chempluschem, 79, $1622-1630$.

18 Liu, D., Wang, Q., \& Hu, J. (2015). Fabrication and characterization of highly ordered Au nanocone array-patterned glass with enhanced SERS and hydrophobicity, Appl. Surf. Sci., 356, 364-369. 